\title{
AGE AND GROWTH OF SMALL RED SCORPIONFISH, SCORPAENA NOTATA (ACTINOPTERYGII: SCORPAENIFORMES: SCORPAENIDAE), A COMMON DISCARD SPECIES FROM THE PORTUGUESE FISHERY
}

\author{
Ana NEVES ${ }^{1 *}$, Vera SEQUEIRA ${ }^{1}$, Ana R. VIEIRA ${ }^{1,2}$, Rafaela B. PAIVA ${ }^{1,2}$, \\ and Leonel S. GORDO ${ }^{1,2}$ \\ ${ }^{1}$ Centro de Oceanografia, Faculdade de Ciências, Universidade de Lisboa, Lisboa, Portugal \\ ${ }^{2}$ Departamento de Biologia Animal, Faculdade de Ciências, Universidade de Lisboa, Lisboa, Portugal
}

\begin{abstract}
Neves A., Sequeira V., Vieira A.R., Paiva R.B., Gordo L.S. 2015. Age and growth of small red scorpionfish, Scorpaena notata (Actinopterygii: Scorpaeniformes: Scorpaenidae), a common discard species from the Portuguese fishery. Acta Ichthyol. Piscat. 45 (1): 13-20.
\end{abstract}

Background. The small red scorpionfish, Scorpaena notata Rafinesque, 1810, appears as a bycatch of Portuguese fisheries. Bycatch species are likely to suffer the same declines as commercial species with which they co-occur but information on those species for Portuguese waters does not exist. In order to increase the knowledge for the Portuguese continental-shelf waters several aspects of the species growth were investigated.

Materials and methods. Age and growth of Scorpaena notata from Portuguese continental-shelf waters were studied using 379 otoliths. A subsample of 70 otoliths, covering all length classes, was read by three of the authors to establish a reading and interpretation pattern. The von Bertalanffy growth model was fitted to sex-specific age-length data. The likelihood ratio tests were used to evaluate the significance of differences on growth parameters between sexes and with the parameters estimated in different areas.

Results. Females dominated in smaller length classes while males prevailed in larger ones, although overall sex ratio did not deviate from $1: 1$. Females ranged from 10.5 to $18.8 \mathrm{~cm}$ total length (TL) and from 1 to 6 years; males ranged from 11.4 to $20.7 \mathrm{~cm} \mathrm{TL}$ and from 1 to 7 years. The von Bertalanffy growth parameters estimated for the Portuguese shelf waters showed significant differences between sexes and were: $L_{\infty}=18.23 \mathrm{~cm} \mathrm{TL}$, $k=0.43 \mathrm{yr}^{-1}, t_{0}=-0.99 \mathrm{yr}$ for females and $L_{\infty}=21.17 \mathrm{~cm} \mathrm{TL}, k=0.28 \mathrm{yr}^{-1}$ and $t_{0}=-1.73 \mathrm{yr}$ for males. The age range found in the Portuguese shelf waters was similar to that found in the Balearic Islands but about half of that found for the Adriatic Sea. Significant differences between growth parameters from the Portuguese coast and those from the Balearic Islands and Adriatic Sea were found.

Conclusion. Estimates of $L_{\infty}$ in the presently reported study were the highest but rather consistent with the maximum length given for the species.

Keywords: bycatch, fisheries, Scorpaenidae, growth model, otoliths, Portuguese shelf

\section{INTRODUCTION}

Marine fisheries stock assessment plays an essential role in ensuring the sustainability of marine resources. Several species, which are not targeted by the fishery, are also caught as bycatch. The role that these fish species may play as prey, competitors, predators, and herbivores make them potential key members of communities and key determinants on how other populations fare (Foster and Vicent 2010).

Bycatch species are typically not the focus of stock assessment efforts because of their limited economic importance, but they may suffer the same population declines as species with which they co-occur (Gertseva and Cope 2011) and life history knowledge of these species is also fundamental to manage their sustainability. Information on the age of individual fish species significantly enhances the quality of studies on population characteristics such as growth, recruitment, mortality, and reproduction, and it is often a prerequisite for more detailed studies on life history strategies and stock assessment (Labropoulou and Papaconstantinou 2000, Cailliet et al. 2001, Stewart and Hughes 2007). The majority of the studies on age and growth of fish involve the determination of age of specimens by counting of growth incre-

\footnotetext{
* Correspondence: Ana Neves, Faculdade de Ciências da Universidade de Lisboa Edifício C2 $5^{\circ}$ piso laboratório 15a Campo Grande 1749-016 Lisboa, Portugal, phone: +351217500824, fax: +351217500028, e-mail: (AN) ananeves73@gmail.com, (VS) vlsequeira@fc.ul.pt, (ARV) arivieira@fc.ul.pt, (RBP) rcpaiva@fc.ul.pt, (LSG)lsgordo@fc.ul.pt.
} 
ments in hard body parts, usually otolith. Otoliths are small calcified structures found in the head of fish that record information in their microstructure and chemistry at different temporal scales related to their growth and environment (Campana 1999).

The small red scorpionfish, Scorpaena notata, Rafinesque, 1810, is a benthic and small-sized scorpion fish found in the depth range of 30-700 m (Hureau and Litvinenko 1986). It occurs in the Mediterranean Sea and in the eastern Atlantic from the Bay of Biscay to Madeira, the Azores, the Canary Islands, and the north-western coast of Africa as far south as Senegal (Eschmeyer 1969). It is also present in the Black Sea as the subspecies Scorpaena notata afimbria Slastenenko, 1935 (see Hureau and Litvinenko 1986).

The small red scorpionfish is generally shorter than $20 \mathrm{~cm}$ of total length (TL) and inhabits preferably rocky bottoms inside crevices or sea grass meadows, but it is also captured by trawlers operating on sandy bottoms in the proximity of hard substrates (Hureau and Litvinenko 1986, Harmelin-Vivien et al. 1989, Morte et al. 2001). In Portuguese waters it appears as a bycatch of several fisheries (Erzini et al. 2006, Gonçalves et al. 2007, Batista et al. 2009).

The presently reported study investigated sex ratio, weight-length relation, and age and growth of Scorpaena notata from the Portuguese continental-shelf waters. A model of the growth of the species for this area was for the first time estimated.

\section{MATERIAL AND METHODS}

Sampling. A total of 400 individuals of small red scorpionfish, Scorpaena notata, were monthly collected on board a trawl fishing boat operating on rocky bottoms along the western Portuguese coast $\left(39^{\circ} 03^{\prime} 20.4^{\prime \prime} \mathrm{N}\right.$, $\left.9^{\circ} 39^{\prime} 54.2^{\prime \prime} \mathrm{W}-38^{\circ} 00^{\prime} 32.7^{\prime \prime} \mathrm{N}, 8^{\circ} 55^{\prime} 30.7^{\prime \prime} \mathrm{W}\right)$ between July 2011 and October 2012 (excluding April due to bad weather conditions). Total length (TL, to the nearest $0.1 \mathrm{~cm}$ ), total weight (TW, to the nearest $0.01 \mathrm{~g}$ ), and sex of each fish were recorded, and the sagitta otoliths (hereby referred as otoliths) were removed, rinsed with water, air dried, and stored in labelled plastic tubes.

Length-weight relation. Significant departs from $1: 1$ sex ratio were investigated using the chi-square test (Legendre and Legendre 1998). The relation between TL $[\mathrm{cm}]$ and TW $[\mathrm{g}]$ was calculated using a power function:

$$
\mathrm{TW}=a \times \mathrm{TL}^{b}
$$

where $a$ is the intercept and $b$ is the slope.

The Student's $t$-test was used to verify the existence of significant differences between sexes and to test the allometry in growth (Zar 1996).

Ageing methodology and validation. Right otoliths were immersed in a 50\% mixture of glycerine and ethanol and read with a binocular microscope (magnification: $12 \times$ ) under reflected light against a dark background. Annual growth increments were counted with the sulcus side down, and from the nucleus towards the posterior region edge. A representative subsample, consisting of 70 otoliths ( 5 for each length class and sex), was read by three of the authors to establish a reading and interpretation pattern and to ensure consistency (Campana 2001). The average percentage error (APE) (Beamish and Fournier 1981), the coefficient of variation (CV) (Chang 1982), and the index of precision $(D)$ (Chang 1982) were used to compare age readings between readers. Bias evaluation was based on age bias plots (Campana et al. 1995) which allow visualizing deviation of the age readings from the $1: 1$ equivalence line, and systematic differences on the ages assigned between readers were investigated with the Bowker-type test for symmetry (Hoenig et al. 1995). As good agreement between readers was achieved, the remaining otoliths were read twice by the first author. When readings differed by one or more growth increment, a third reading was made; if the third reading differed from the previous two, the otolith was discarded. Age readings were compared as above. To validate the seasonality of growth increment deposition, the relative frequency of an opaque zone on the otolith margin was plotted by month (Beckman and Wilson 1995, Panfili and MoralesNin 2002).

Growth model. Once the age estimates were validated, the von Bertalanffy growth model (von Bertalanffy 1938) was fitted to sex-specific age-length data. The likelihood ratio tests (Kimura 1980) were used to evaluate the significance of differences on growth parameters between sexes and with the parameters estimated in different areas by other authors. The von Bertalanffy growth model and the likelihood ratio tests were estimated with the Fishmethods package (Nelson 2013) in R software v.3.0.2.

\section{RESULTS}

Length-weight relation. A total of 400 specimens were sampled: 209 females (52\%) and 191 males (48\%). The overall sex-ratio (F : M) did not differ significantly from $1: 1\left(\chi^{2}=0.81, \mathrm{df}=1, P=0.3681\right)$. However significant differences were present when length classes were analyzed (Fig. 1). Females were dominant in TL classes below $16 \mathrm{~cm}\left(5.1: 1, \chi^{2}=64.0, \mathrm{df}=1, P<0.0001\right)$ and males prevailed in TL classes above $17 \mathrm{~cm}\left(1: 4.1, \chi^{2}=53.9\right.$,

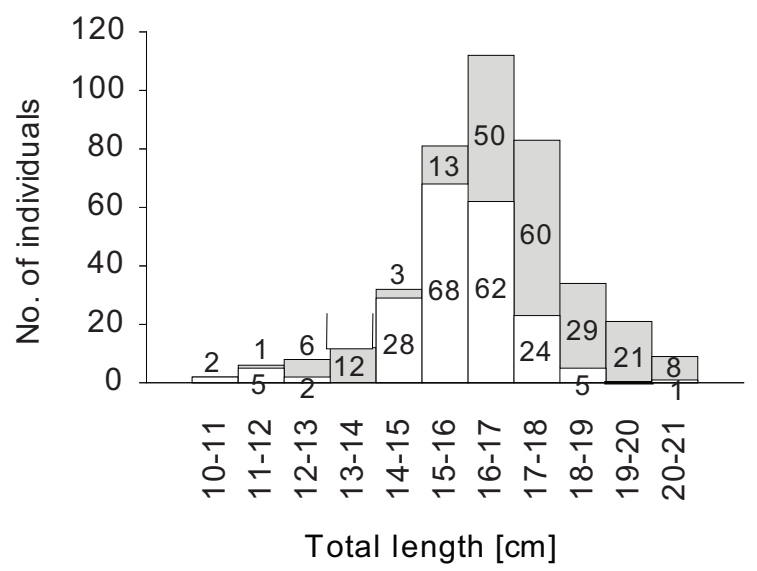

Fig. 1. Length frequency distribution of small red scorpionfish, Scorpaena notata, from Portuguese continental-shelf waters (females: white; males: grey) 
$\mathrm{df}=1, P<0.0001)$. For the $16-17 \mathrm{~cm}$ TL class, sex ratio did not differ significantly from $1: 1\left(1.24: 1, \chi^{2}=1.29\right.$, $\mathrm{df}=1, P=0.2568)$. The equations that express the length-weight relation for the small red scorpionfish were: $\mathrm{TW}=0.0150 \times \mathrm{TL}^{3.1164}, r=0.94$ for females and $\mathrm{TW}=0.0167 \times \mathrm{TL}^{3.0658}, r=0.93$ for males. Both sexes showed positive allometric growth (paired $t$-test, females: $t$-test $=19.39, \mathrm{df}=208, P<0.0001 ;$ males: $t$-test $=9.85$, $\mathrm{df}=190, P<0.0001)$. The allometric coefficient of the regression in females was significantly higher than in males $(t$-test $=5.63, \mathrm{df}=388, P<0.0001)$.

Ageing methodology and validation. Small red scorpionfish otoliths showed the typical pattern for teleosts: alternations of translucent and opaque increments laid down around an opaque nucleus, although two or more opaque zones often appear forming false increments adding some difficult to determine the age of this species (Fig. 2). The analysis of the incidence of opaque and translucent zones at the otolith margin suggests that the growth increments are formed annually with the opaque ones occurring more frequently in spring and summer months, and translucent edges dominating during autumn and winter (Fig. 3).

The three readers determined the age of 70 small red scorpionfish right otoliths, and reader 1 read all right otoliths twice. Indices of precision for age readings within and between readers are presented in Table 1, and the age-bias plots in Fig. 4. The estimates of APE, CV, and $D$ within and between readers reflected a good precision of age readings. Age-bias plots (Fig. 4) and the test of symmetry $\left(\chi_{\text {R1vsR } 2}^{2}=11, \mathrm{df}=7, P=0.1386 ; \chi_{\mathrm{R} 1 \mathrm{vsR} 3}^{2}=8.67\right.$, $\left.\mathrm{df}=5, P=0.1231 ; \chi_{\mathrm{R} 2 \mathrm{vsR} 3}^{2}=8.33, \mathrm{df}=7, P=0.3041\right)$ showed that age disagreement was due to simple random error and not to a systematic difference between readers. Growth model. For ageing estimate 194 females $(10.5 \mathrm{~cm}$ to $18.8 \mathrm{~cm}$ TL and 1 to 6 years), and 185 males $(11.4 \mathrm{~cm}$ to $20.7 \mathrm{~cm} \mathrm{TL}, 1$ to 7 years) were used. The remaining individuals $(6.2 \%)$ showed broken or non-interpretable otoliths. Female and male age-length keys are shown in Table 2 and 3, respectively. Significant differences

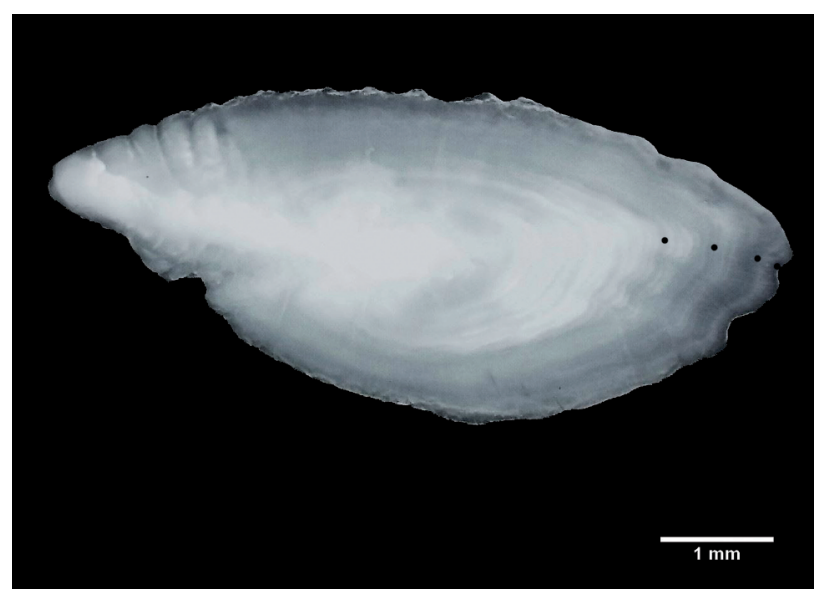

Fig. 2. Sagittal otolith of small red scorpionfish, Scorpaena notata, from Portuguese continental-shelf waters, showing the annulus deposition pattern for a 4-years-old female, $14.6 \mathrm{~cm}$ total length between males and females growth parameters were found (likelihood ratio test: $\chi^{2}=18.26, \mathrm{df}=3, P<0.0001$ ) and the von Bertalanffy growth curves are presented in Fig. 5. The estimated von Bertalanffy growth parameters obtained are presented in Table 4, as well as a summary of the parameters and the results of Likelihood ratio test performed with other published works on small red scorpionfish.

\section{DISCUSSION}

Bycatch and discarding have numerous, generally undesirable consequences which affect marine ecosystem structure and function Furthermore they offer no obvious economic benefit to fishers and therefore represent additional unintended mortality (Bellido et al. 2011). Decreasing discards has been put forward as one of the main reform challenges of the Common Fisheries Policy (CFP) of the European Union (Morandeau et al. 2014), but designing effective bycatch mitigation programmes requires, among others, an understanding of the life histories of target and non-target species (O'Keefe et al. 2014).

One of the species caught as bycatch of several fisheries operating in the Portuguese coast is the small red scorpionfish. Unlike other regions such as the Balearic Islands (Ordines et al. 2009), in Portugal this species has no commercial value and is immediately discarded onboard. However information on such species is also essential to assess the ecosystem condition and therefore manage fisheries properly.

Results from this study indicate the bias of females towards smaller lengths and of males towards larger ones as already reported for other scorpaenid species such as Scorpaena maderensis Valenciennes, 1833 (see La Mesa et al. 2005), Scorpaena loppei Cadenat, 1943 (see Ordines et al. 2012), Pontinus kuhlii (Bowdich, 1825) (see Paiva et al. 2013), Helicolenus dactylopterus (Delaroche, 1809) (see Massuti et al. 2000), and also for Scorpaena notata of Balearic Islands (Ordines et al. 2009). The reproductive strategy showed by several species within the scorpaenid family such as the development of a gelatinous matrix

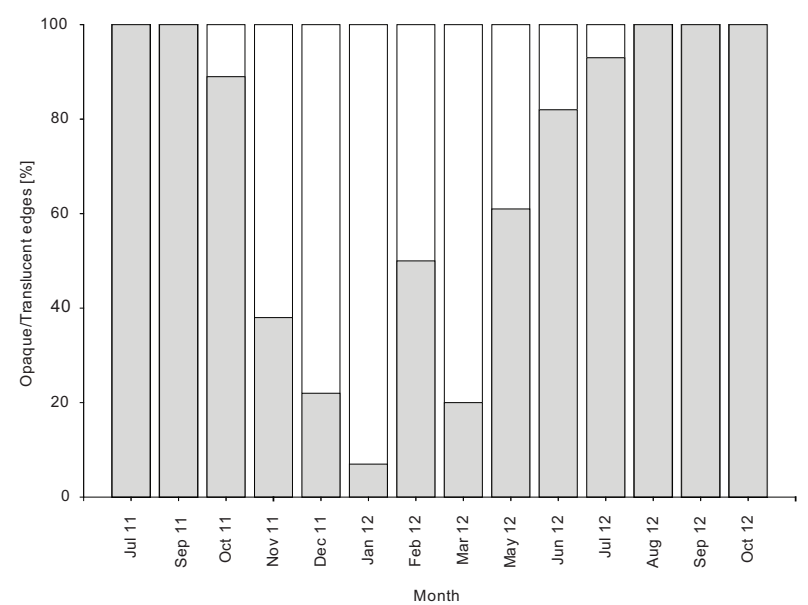

Fig. 3. Monthly variation pattern of the percentage of opaque (grey) and translucent (white) edges in the otolith of small red scorpionfish, Scorpaena notata 
within the ovary (Muñoz 2010) imply that females have a higher energetic cost during reproduction than males and can justify the growth differences between sexes. Despite this length class bias, the majority of the published works showed no deviation from an overall sex ratio of 1 : 1 (Massutí et al. 2000, Ordines et al. 2009, 2012, Sequeira et al. 2009, Paiva et al. 2013). Curiously, for the small red scorpionfish, Scarcella et al. (2011) and Muñoz et al. (2005) reported a sex ratio biased in favour of males but no significant differences in length classes by sex. However only 6 females larger than $17 \mathrm{~cm}$ were caught in the Adriatic Sea and the larger specimen used by Muñoz et al. (2005) had $16.7 \mathrm{~cm}$, suggesting that males are probably larger than females.

Age data is one of the most influential biological variables (Campana 2001), and otoliths are widely accepted as the best ageing structure for many teleost fish. However, the process of estimating fish age incorporates several sources of error, mainly a process error associated with the structure being examined and error due to the element of subjectivity required of all age estimations (Campana 2001). Although several authors suggest the use of crosssections as a more reliable ageing method, Worthington et al. (1995) advocate the use of ageing methods that are uncomplicated and cost effective, so long as they provide reliable data. Also, the cross-section method is fundamental for long-lived, slow-growing species, since differentiating closely spaced growth increments near the edge is very difficult in whole otoliths. Even so, in some long-lived scorpaeniform species (e.g., Helicolenus dactylopterus; see Sequeira et al. 2013) studies were made to compare direct readings with cross-sections and no advantages were found using the latter methodology.

The otolith structure of the small red scorpionfish permits a fairly easy identification of growth increments (as shown by the low percentage of rejected otoliths) and since the precision indices obtained both within and between readers (two of them with large experience in age assignment even for this family) were lower than those referred in most literature $(\mathrm{CV}<7.6 \%$ and $\mathrm{APE}<5.5 \%$ (Campana 2001)), and much lower than those referred for this species

\section{Table 1}

Indices of precision for age readings of small red scorpionfish, Scorpaena notata, from the Portuguese continental-shelf waters, within and between readers

\begin{tabular}{lcc}
\hline \multirow{2}{*}{ Index } & \multicolumn{2}{c}{ Index comparison } \\
\cline { 2 - 3 } & Reader 1 & Between readers \\
\hline APE [\%] & 2.477 & 5.267 \\
CV [\%] & 2.480 & 6.842 \\
$D[\%]$ & 1.754 & 3.95 \\
\hline
\end{tabular}

$\mathrm{APE}=$ average percentage error, $\mathrm{CV}=$ coefficient of variation, $D=$ index of precision.
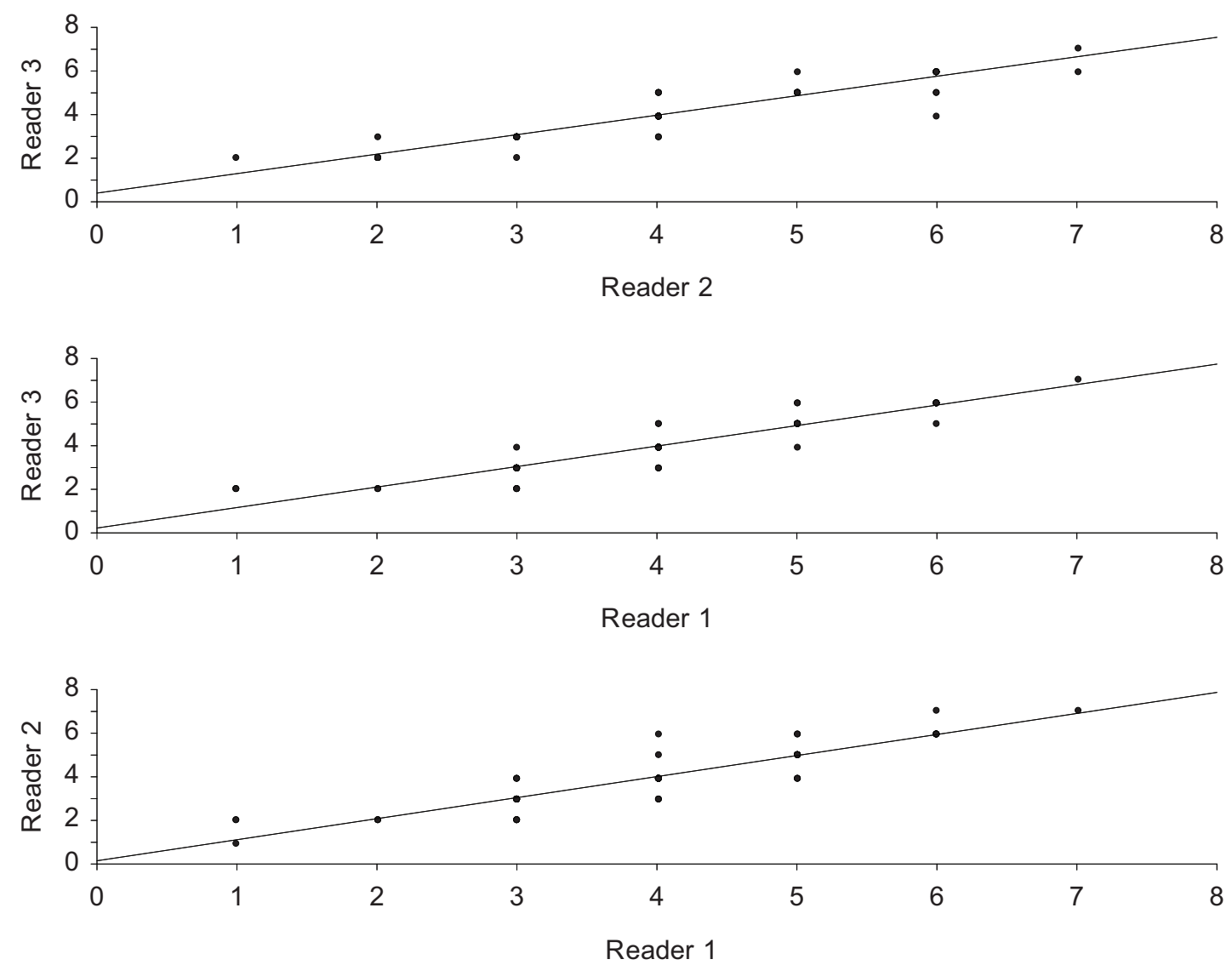

Fig. 4. Age bias plots for the readings comparisons between readers for small red scorpionfish, Scorpaena notata, from Portuguese continental-shelf waters; The $45^{\circ}$ line represents $100 \%$ agreement 
Age-length key for females of the small red scorpionfish, Scorpaena notata,

Table 2 from the Portuguese continental-shelf waters for the period of 2011-2012

\begin{tabular}{|c|c|c|c|c|c|c|c|}
\hline \multirow{2}{*}{$\mathrm{TL}[\mathrm{cm}]$} & \multicolumn{6}{|c|}{ Age class [year] } & \multirow{2}{*}{$n$} \\
\hline & 1 & 2 & 3 & 4 & 5 & 6 & \\
\hline $10-11$ & 2 & & & & & & 2 \\
\hline $11-12$ & & 4 & 1 & & & & 5 \\
\hline $12-13$ & & 2 & & & & & 2 \\
\hline $13-14$ & & 2 & 9 & & & & 11 \\
\hline $14-15$ & & 4 & 16 & 5 & 1 & & 26 \\
\hline $15-16$ & & & 23 & 37 & 3 & & 63 \\
\hline $16-17$ & & & 6 & 37 & 16 & & 59 \\
\hline $17-18$ & & & & 9 & 11 & 2 & 22 \\
\hline $18-19$ & & & 1 & & 2 & 1 & 4 \\
\hline$n$ & 2 & 12 & 56 & 88 & 33 & 3 & 194 \\
\hline Mean & 10.60 & 13.00 & 14.99 & 16.03 & 16.68 & 17.40 & \\
\hline SD & 0.14 & 1.06 & 1.09 & 0.75 & 1.04 & 0.53 & \\
\hline
\end{tabular}

$\mathrm{TL}=$ total length, $n=$ number of individuals, Mean = mean total length, $\mathrm{SD}=$ standard deviation.

Table 3

Age-length key for males of the small red scorpionfish, Scorpaena notata, from the Portuguese continental-shelf waters for the period 2011-2012

\begin{tabular}{|c|c|c|c|c|c|c|c|c|}
\hline \multirow{2}{*}{$\mathrm{TL}[\mathrm{cm}]$} & \multicolumn{7}{|c|}{ Age classes [years] } & \multirow{2}{*}{$n$} \\
\hline & 1 & 2 & 3 & 4 & 5 & 6 & 7 & \\
\hline $11-12$ & 1 & & & & & & & 1 \\
\hline $12-13$ & & 3 & 3 & & & & & 6 \\
\hline $14-15$ & & & 3 & & & & & 3 \\
\hline $15-16$ & & & 8 & 5 & & & & 13 \\
\hline $16-17$ & & & 14 & 27 & 9 & & & 50 \\
\hline $17-18$ & & & 4 & 23 & 25 & 6 & & 58 \\
\hline $18-19$ & & & & 9 & 11 & 5 & 1 & 26 \\
\hline $19-20$ & & & & 2 & 6 & 12 & 1 & 21 \\
\hline $20-21$ & & & & & & 4 & 3 & 7 \\
\hline$n$ & 1 & 3 & 32 & 66 & 51 & 27 & 5 & \\
\hline Mean & 11.40 & 12.73 & 15.69 & 17.08 & 17.69 & 18.95 & 19.84 & 185 \\
\hline SD & & 0.15 & 1.41 & 0.86 & 0.89 & 0.94 & 1.02 & \\
\hline
\end{tabular}

$\mathrm{TL}=$ total length, $n=$ number of individuals, Mean = mean total length, $\mathrm{SD}=$ standard deviation.

Table 4

The von Bertalanffy growth parameters for the small red scorpionfish, Scorpaena notata from different areas

\begin{tabular}{|c|c|c|c|c|c|c|c|c|c|c|c|c|}
\hline \multirow{2}{*}{ Area } & \multirow{2}{*}{ Method } & \multirow{2}{*}{ Reference } & \multirow{2}{*}{ Sex } & \multirow{2}{*}{$L_{\infty}[\mathrm{cm}]$} & \multirow{2}{*}{$k$ year $^{-1}$} & \multirow{2}{*}{$t_{0}$ year } & \multirow{2}{*}{$n$} & \multirow{2}{*}{$\begin{array}{c}\text { Age } \\
\text { [year] }\end{array}$} & \multirow{2}{*}{$\begin{array}{l}\text { Size } \\
{[\mathrm{cm}]}\end{array}$} & \multicolumn{3}{|c|}{ Comparison } \\
\hline & & & & & & & & & & chisq & df & P \\
\hline \multirow{2}{*}{ Balearic I. } & \multirow{2}{*}{ WO } & \multirow{2}{*}{ Ordines et al. 2009} & $\mathrm{~F}$ & $17.9^{\mathrm{S}}$ & 0.19 & -2.27 & 471 & $0-6$ & $4-17$ & 38.82 & 3 & $<0.0001$ \\
\hline & & & M & & 0.24 & -1.74 & 476 & $0-8$ & $5-18$ & 45.98 & 3 & $<0.0001$ \\
\hline \multirow{2}{*}{ N Adriatic } & \multirow{2}{*}{ WSO } & \multirow{2}{*}{ Scarcella et al. 2011} & $\mathrm{~F}$ & $15.57(0.33)$ & $0.35(0.5)$ & $-2.06(0.43)$ & 225 & $0-16$ & $4.7-19.9$ & 31.97 & 3 & $<0.0001$ \\
\hline & & & M & $16.32(0.30)$ & $0.46(0.5)$ & $-1.17(0.21)$ & 285 & $0-14$ & $6.5-19.8$ & 40.52 & 3 & $<0.0001$ \\
\hline \multirow{2}{*}{ Portugal } & \multirow{2}{*}{ WO } & \multirow{2}{*}{ This work } & $\mathrm{F}$ & $18.23(0.61)$ & $0.43(0.08)$ & $-0.99(0.43)$ & 194 & $0-6$ & $10.5-18.8$ & & & \\
\hline & & & M & $21.17(1.11)$ & $0.28(0.08)$ & $-1.73(0.77)$ & 185 & $0-7$ & $11.4-20.7$ & & & \\
\hline
\end{tabular}

$L_{\infty}=$ asymptotic length, $k=$ growth rate, $t_{0}=$ hypothetical age when size is zero, $n=$ number of specimens, Comparison $=$ results of the likelihood ratio test comparison between areas, chisq $=$ Likelihood ratio chi square statistic value, $\mathrm{df}=\mathrm{degrees}$ of freedom, $P$ = probability; $\mathrm{WO}=$ whole otoliths, $\mathrm{WSO}=$ whole and sectioned otoliths; $\mathrm{F}=$ female, $\mathrm{M}=$ male; (asymptotic standard errors of the estimates are shown within brackets). 


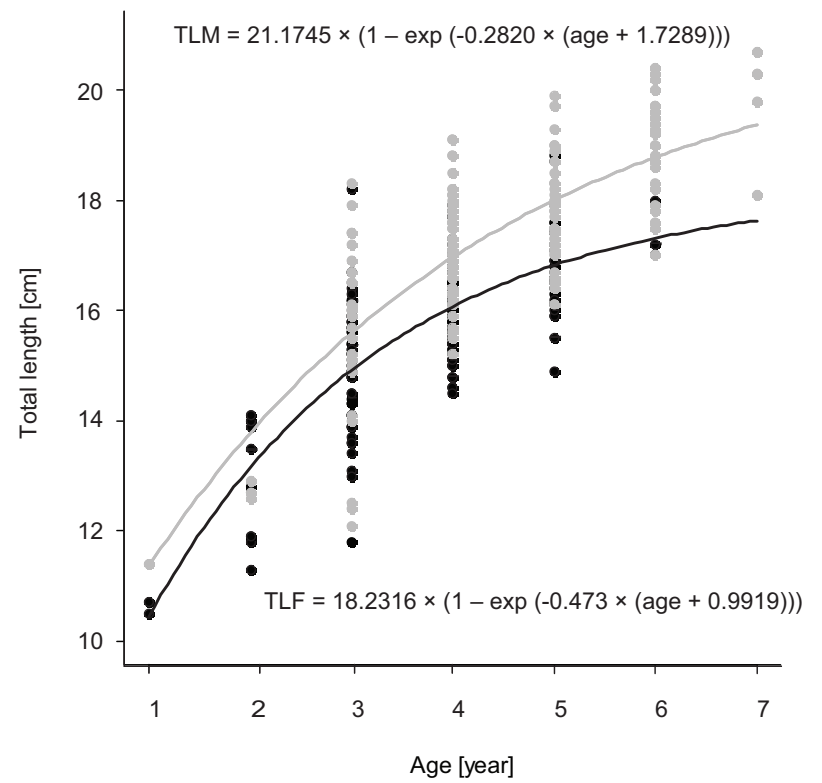

Fig. 5. The von Bertalanffy growth model for females (black) and males (grey) of small red scorpionfish, Scorpaena notata, from Portuguese continental-shelf waters; TLM: males total length, TLF: females total

$(\mathrm{CV}=11.6 \%$ and $\mathrm{APE}=8.12 \%$; Scarcella et al. 2011) the ageing method used in this study seems to be adequate.

The age range found in the Portuguese continentalshelf waters ( 1 to 6 years for females and 1 to 7 years for males) was similar to that found in the Balearic Islands by Ordines et al. (2009) but about half of that found by Scarcella et al. (2011) in the Adriatic Sea. These authors used sectioned otoliths to estimate the age of larger individuals and obtained a maximum age of 16 years for a $16 \mathrm{~cm}$ female. Nevertheless these authors aged approximately $76 \%$ of the individuals with $1-4$ years old and less than $12 \%$ were aged with more than 7 years. They also showed a large age range for each length class above $15 \mathrm{~cm}$ (e.g., between 2 and 15 years for females with $15 \mathrm{~cm}$ ). It is known that thin otolith section may add difficulty in locate true increments since false rings became more evident (Morales-Nin et al. 2002).

Other species of the genus Scorpaena seem to have a similar age pattern to that found in this study. The two smaller species of the genus, S. maderensis and S. loppei which reach about $13 \mathrm{~cm}$ TL, have age estimations of a maximum of 5 years (La Mesa et al. 2005 and Ordines et al. 2012, respectively). For Scorpaena porcus Linnaeus, 1758, a species which attain slightly larger length than Scorpaena notata, a maximum of 11 years was estimated (Jardas and Pallaoro 1992) but the majority of the studies refer a maximum of 8 years (Bilgin and Çelik 2009, Demirhan and Can 2009, La Mesa et al. 2010).

Significant differences between the growth parameters for the Portuguese coast and those for the Balearic Islands and Adriatic Sea were found. Estimates of $L_{\infty}$ in the presently reported study were higher than those found by the other authors, although the maximum length observed for females was slightly higher than the asymptotic length estimated. One possible reason lies with the available material for this study since we worked with samples from commercial fishery and therefore a lack of smaller individuals is notorious due to the gear selectivity. Regarding the growth rate, specimens from the Portuguese coast were the ones that presented the highest growth rate, specially the females. Abiotic factors and temperature in particular have been considered to influence growth rate, with the specimens from warmer waters showing a faster growth rate (Silva and Gordo 1997) but, in the present case, all specimens in comparison were caught in warm waters. Other explanations may lie in the specific life history parameters from each population, and sampling issues such as the range of length used.

This is the first reference for the small red scorpionfish growth in Portuguese shelf waters. Since a larger importance is being given to discards in fisheries (Malaquias et al. 2006, Catchpole and Gray 2010, Bellido et al. 2011, Campos et al. 2014) information on such species plays an increasingly important and essential role for the correct management of fisheries and environment. The information given by this study will need to be complemented by reproductive and mortality data in order to properly document the species life history patterns. However according to the knowledge gathered about the species, one possible action to mitigate this bycatch fishery is to make an effort, using a marketing strategy, to introduce this species in the diet of consumers since other members of the family Scorpaenidae attain high prices in the Portuguese market.

\section{ACKNOWLEDGEMENTS}

We would like to thank Pedro Gomes and the crew of the stern trawler FV Sagittarius (IMO 9096870) by providing the specimens used in this study. This study was partially supported by the project PROMAR 31-03-05FEP-8, and by the Fundação para a Ciência e Tecnologia (FCT), through individual grants awarded to: Vera Sequeira (SFRH/BPD/70200/2010), Ana Rita Vieira (SFRH/BD/73506/2010), Rafaela Barros Paiva (SFRH/BD/80268/2011), and Ana Neves (SFRH/BD/92769/2013).

\section{REFERENCES}

Batista M.I., Teixeira C.M., Cabral H.N. 2009. Catches of target species and bycatches of an artisanal fishery: The case study of a trammel net fishery in the Portuguese coast. Fisheries Research 100 (2): 167-177. DOI: 10.1016/j.fishres.2009.07.007

Beamish R.J., Fournier D.A. 1981. A method for comparing the precision of a set of age determinations. Canadian Journal of Fisheries and Aquatic Sciences 38 (8): 982-983. DOI: 10.1139/f81-132

Beckman D.W., Wilson C.A. 1995. Seasonal timing of opaque zone formation in fish otoliths. Pp. 27-43. In: Secor D.H., Dean J.M., Campana S.E. (eds.) Recent developments in fish otolith research. University of South Carolina Press, Columbia, SC, USA. 
Bellido J.M., Santos M.B., Pennino M.G., Valeiras X., Pierce G.J. 2011. Fishery discards and bycatch: Solutions for an ecosystem approach to fisheries management? Hydrobiologia. 670 (1): 317-333.

DOI: $10.1007 / \mathrm{s} 10750-011-0721-5$

Bilgin S., Çelik E.Ş. 2009. Age, growth and reproduction of the black scorpionfish, Scorpaena porcus (Pisces, Scorpaenidae), on the Black Sea coast of Turkey. Journal of Applied Ichthyology 25 (1): 55-60.

DOI: $10.1111 / \mathrm{j} .1439-0426.2008 .01157 . x$

Cailliet G.M., Andrews A.H., Burton E.J., Watters D.L., Kline D.E., Ferry-Graham L.A. 2001. Age determination and validation studies of marine fishes: Do deep-dwellers live longer? Experimental Gerontology 36 (4-6): 739-764. DOI: $10.1016 / \mathrm{S} 0531-5565(00) 00239-4$

Campana S.E. 1999. Chemistry and composition of fish otoliths: Pathways, mechanisms and applications. Marine Ecology Progress Series 188: 263-297. DOI: $10.3354 /$ meps 188263

Campana S.E. 2001. Accuracy, precision and quality control in age determination, including a review of the use and abuse of age validation methods. Journal of Fish Biology 59 (2): 197-242. DOI: $10.1111 /$ j.1095-8649.2001.tb00127.x

Campana S.E., Annand M.C., McMillan J.I. 1995. Graphical and statistical methods for determining the consistency of age determinations. Transactions of the American Fisheries Society 124 (1): 131-138.

DOI: 10.1577/1548-8659(1995)124<0131:GASMFD >2.3.CO;2

Campos A., Fonseca P., Henriques V., Parente J. 2014. Reducing by-catch in Portuguese trawl fisheries with a view on a future discard-ban at EU level-a technological approach. Pp.1069-1074. In: Soares C.G., Pena F.L. (eds.) Developments in maritime transportation and exploitation of sea resources. IMAM 2013. Vol. 2. Taylor and Francis Group, London, UK.

Catchpole T.L., Gray T.S. 2010. Reducing discards of fish at sea: A review of European pilot projects. Journal of Environmental Management 91 (3): 717-723.

DOI: 10.1016/j.jenvman.2009.09.035

Chang W.Y.B. 1982. A statistical method for evaluating the reproducibility of age determination. Canadian Journal of Fisheries and Aquatic Sciences 39 (8): 1208-1210

DOI: $10.1139 / \mathrm{f} 82-158$

Demirhan S.A., Can M.F. 2009. Age, growth and food composition of Scorpaena porcus (Linnaeus, 1758) in the southeastern Black Sea. Journal of Applied Ichthyology 25 (2): 215-218. DOI: 10.1111/j.1439-0426.2009.01217.x

Erzini K., Gonçalves J.M.S., Bentes L., Moutopoulos D.K., Casal J.A.H., Soriguer M.C., Puente E., Errazkin L.A., Stergiou K.I. 2006. Size selectivity of trammel nets in southern European small-scale fisheries. Fisheries Research 79 (1-2): 183-201.

DOI: $10.1016 /$ j.fishres.2006.03.004

Eschmeyer W.N. 1969. A systematic review of the scorpionfishes of the Atlantic Ocean (Pisces, Scorpaenidae). Occasional Papers California Academy of Sciences No. 79.

Foster S.J., Vincent A.C.J. 2010. Using life-history information to assess potential effects of shrimp trawling on small fishes. Journal of Fish Biology 76 (10): 2434-2454.

DOI: $10.1111 / \mathrm{j} .1095-8649.2010 .02631 . \mathrm{x}$

Gertseva V.V., Cope J.M. 2011. Population dynamics of splitnose rockfish (Sebastes diploproa) in the Northeast Pacific Ocean. Ecological Modelling 222 (4): 973-981.

DOI: $10.1016 /$ j.ecolmodel.2010.12.003

Gonçalves J.M.S., Stergiou K.I., Hernando J.A., Puente E., Moutopoulos D.K., Arregi L., Soriguer M.C., Vilas C., Coelho R., Erzini K. 2007. Discards from experimental trammel nets in southern European small-scale fisheries. Fisheries Research 88 (1-3): 5-14.

DOI: 10.1016/j.fishres.2007.06.017

Harmelin-Vivien M.L., Kaim-Malka R.A., Ledoyer M., JacobAbraham S.S. 1989. Food partitioning among scorpaenid fishes in Mediterranean seagrass beds. Journal of Fish Biology 34 (5): 715-734.

DOI: 10.1111/j.1095-8649.1989.tb03352.x

Hoenig J.M., Morgan M.J., Brown C.A. 1995. Analysing differences between two age determination methods by tests of symmetry. Canadian Journal of Fisheries and Aquatic Sciences 52 (2): 364-368.

DOI: $10.1139 / \mathrm{f} 95-038$

Hureau J.C., Litvinenko N.I. 1986. Scorpaenidae. Pp. 1211-1229. In: Whitehead P.J.P., Bauchot M.-L., Hureau J.-C., Nielsen J., Tortonese E. (eds.) Fishes of the north-eastern Atlantic and the Mediterranean. Vol. 3. UNESCO, Paris.

Jardas I., Pallaoro A. 1992. Age and growth of black scorpionfish, Scorpaena porcus L., 1758 in the Adriatic Sea. Rapport de la Commission international de la mer Méditerranée 33: 296.

Kimura M. 1980. A simple method for estimating evolutionary rates of base substitutions through comparative studies of nucleotide sequences. Journal of Molecular Evolution 16 (2): $111-120$

DOI: $10.1007 / \mathrm{BF} 01731581$

Labropoulou M., Papaconstantinou C. 2000. Comparison of otolith growth and somatic growth in two macrourid fishes. Fisheries Research 46 (1-3): 177-188.

DOI: $10.1016 / \mathrm{S} 0165-7836(00) 00144-2$

La Mesa M., La Mesa G., Micalizzi M. 2005. Age and growth of Madeira scorpionfish, Scorpaena maderensis Valenciennes, 1833, in the central Mediterranean. Fisheries Research 74 (1-3): 265-272.

DOI: 10.1016/j.fishres.2005.01.018

La Mesa M., Scarcella G., Grati F., Fabi G. 2010. Age and growth of the black scorpionfish, Scorpaena porcus (Pisces: Scorpaenidae) from artificial structures and natural reefs in the Adriatic Sea. Scientia Marina 74 (4): 677-685.

DOI: $10.3989 /$ scimar.2010.74n4677

Legendre P., Legendre L. 1998. Numerical ecology. 2nd English edition. Elsevier, Amsterdam.

Malaquias M.A.E., Bentes L., Erzini K., Borges T.C. 2006. Molluscan diversity caught by trawling fisheries: A case study in southern Portugal. Fisheries Management and Ecology 13 (1): 39-45.

DOI: $10.1111 / j .1365-2400.2006 .00474 . x$

Massutí E., Morales-Nin B., Moranta J. 2000. Age and growth of blue-mouth, Helicolenus dactylopterus (Osteichthyes: 
Scorpaenidae), in the western Mediterranean. Fisheries Research 46 (1-3): 165-176.

DOI: $10.1016 / \mathrm{S} 0165-7836(00) 00143-0$

Morales-Nin B., Canha Â., Casas M., Figueiredo I., Gordo L.S., Gordon J.D.M., Gouveia E., Piñeiro C.G., Reis S., Reis A., Swan S.C. 2002. Intercalibration of age readings of deepwater black scabbardfish, Aphanopus carbo (Lowe, 1839). ICES Journal of Marine Science 59: 352-364. DOI: $10.1006 /$ jmsc.2001.1154

Morandeau G., Macher C., Sanchez F., Bru N., Fauconnet L., Caill-Milly N. 2014. Why do fishermen discard? Distribution and quantification of the causes of discards in the Southern Bay of Biscay passive gear fisheries. Marine Policy 48: 30-38.

DOI: 10.1016/j.marpol.2014.02.022

Morte S., Redón M.J., Sanz-Brau A. 2001. Diet of Scorpaena porcus and Scorpaena notata (Pisces: Scorpaenidae) in the western Mediterranean. Cahiers de Biologie Marine 42 (4): 333-344.

Muñoz M. 2010. Reproduction in Scorpaeniformes. Pp. 65-90. In: Cole K.S. (ed.) Reproduction and sexuality in marine fishes: Patterns and processes. University of California Press, Berkeley, CA, USA.

Muñoz M., Sàbat M., Vila S., Casadeval M. 2005. Annual reproductive cycle and fecundity of Scorpaena notata (Teleostei: Scorpaenidae). Scientia Marina 69 (4): 555-562.

Nelson G.A. 2013. Fishmethods: fishery science methods and models in R. http://cran.r-project.org/web/packages/fishmethods/index.html. Accessed 20 February 2014.

O'Keefe C.E., Cadrin S.X., Stokesbury K.D.E. 2014. Evaluating effectiveness of time/area closures, quotas/caps, and fleet communications to reduce fisheries bycatch. ICES Journal of Marine Science 71 (5): 1286-1297. DOI: $10.1093 /$ icesjms/fst063

Ordines F., Quetglas A., Massutí E., Moranta J. 2009. Habitat preferences and life history of the red scorpion fish, Scorpaena notata, in the Mediterranean. Estuarine, Coastal and Shelf Science 85: 537-546.

DOI: 10.1016/j.ecss.2009.09.020

Ordines F., Valls M., Gouraguine A. 2012. Biology, feeding, and habitat preferences of Cadenat's rockfish, Scorpaena loppei (Actinopterygii: Scorpaeniformes: Scorpaenidae), in the Balearic Islands (western Mediterranean). Acta Ichthyologica et Piscatoria 42 (1): 21-30. DOI: $10.3750 /$ aip2011.42.1.03
Paiva R.B., Neves A., Sequeira V., Vieira A.R., Costa M.J., Domingos I., Gordo L.S. 2013. Age, growth and mortality of Pontinus kuhlii (Bowdich, 1825) (Scorpaeniformes: Scorpaenidae) in the Gorringe, Ampère, Unicorn and Lion seamounts. Scientia Marina 77 (1): 95-104.

DOI: $10.3989 /$ scimar.03632.28B

Panfili J., Morales-Nin B. 2002. Semi-direct validation. Pp. 129-134. In: Panfili J., de Pontual H., Troadec H., Wright P.J. (eds.) Manual of fish sclerochronology. Ifremer- IRD co-edition, Brest, France.

Scarcella G., La Mesa M., Grati G., Polidori P. 2011. Age and growth of the small red scorpionfish, Scorpaena notata Rafinesque, 1810, based on whole and sectioned otolith readings. Environmental Biology of Fishes 91 (4): 369-378. DOI: $10.1007 / \mathrm{s} 10641-011-9796-0$

Sequeira V., Neves A., Vieira A.R., Figueiredo I., Gordo L.S. 2009. Age and growth of bluemouth, Helicolenus dactylopterus, from the Portuguese continental slope. ICES Journal of Marine Science 66 (3): 524-531.

DOI: $10.1093 /$ icesjms/fsp010

Sequeira V., Vieira A.R., Neves A., Paiva R.B., Canário A., Gordo L.S. 2013. Whole or sectioned otoliths? Choosing the best method for aging bluemouth, Helicolenus dactyloterus (Delaroche, 1809). Fisheries Research 147: 235-239. DOI: 10.1016/j.fishres.2013.06.012

Silva M.N., Gordo L.S. 1997. Age, growth and reproduction of the black goby, Gobius niger, from Óbidos Lagoon, Portugal. Cahiers de Biologie 38 (3): 175-180.

Stewart J., Hughes M. 2007. Age validation and growth of three commercially important hemiramphids in south-eastern Australia. Journal of Fish Biology 70 (1): 65-82. DOI: $10.1111 / \mathrm{j} .1095-8649.2006 .01256 . \mathrm{x}$

von Bertalanffy L. 1938. A quantitative theory of organic growth (inquiries of growth laws II). Human Biology 10 (2): 181-213.

Worthington D.G., Fowler A.J., Doherty P.J. 1995. Determining the most efficient method of age determination for estimating the age structure of a fish population. Canadian Journal of Fisheries and Aquatic Sciences 52 (11): 2320-2326. DOI: $10.1139 / \mathrm{f} 95-224$

Zar J.H. 1996. Biostatistical analysis. 3rd edn. Prentice Hall, Upper Saddle River, NJ, USA.

Received: 2 June 2014 Accepted: 29 September 2014 Published electronically: 31 March 2015 